\title{
Lithium Enhances the GABAergic Synaptic Activities on the Hypothalamic Preoptic Area (hPOA) Neurons
}

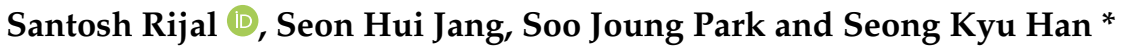 \\ Department of Oral Physiology, School of Dentistry \& Institute of Oral Bioscience, Jeonbuk National University, \\ Jeonju 54896, Korea; santoshrijal047@gmail.com (S.R.); sunnyjang@jbnu.ac.kr (S.H.J.); soopark@jbnu.ac.kr (S.J.P.) \\ * Correspondence: skhan@jbnu.ac.kr; Tel.: +82-63-270-4030; Fax: +82-63-270-4004
}

Citation: Rijal, S.; Jang, S.H.; Park, S.J.; Han, S.K. Lithium Enhances the GABAergic Synaptic Activities on the Hypothalamic Preoptic Area (hPOA) Neurons. Int. J. Mol. Sci. 2021, 22, 3908. https://doi.org/10.3390/ ijms22083908

Academic Editors: Julie Perroy and Enora Moutin

Received: 15 February 2021

Accepted: 8 April 2021

Published: 9 April 2021

Publisher's Note: MDPI stays neutral with regard to jurisdictional claims in published maps and institutional affiliations.

Copyright: (c) 2021 by the authors. Licensee MDPI, Basel, Switzerland. This article is an open access article distributed under the terms and conditions of the Creative Commons Attribution (CC BY) license (https:/ / creativecommons.org/licenses/by/ $4.0 /)$.

\begin{abstract}
Lithium $\left(\mathrm{Li}^{+}\right)$salt is widely used as a therapeutic agent for treating neurological and psychiatric disorders. Despite its therapeutic effects on neurological and psychiatric disorders, it can also disturb the neuroendocrine axis in patients under lithium therapy. The hypothalamic area contains GABAergic and glutamatergic neurons and their receptors, which regulate various hypothalamic functions such as the release of neurohormones, control circadian activities. At the neuronal level, several neurotransmitter systems are modulated by lithium exposure. However, the effect of $\mathrm{Li}^{+}$on hypothalamic neuron excitability and the precise action mechanism involved in such an effect have not been fully understood yet. Therefore, $\mathrm{Li}^{+}$action on hypothalamic neurons was investigated using a whole-cell patch-clamp technique. In hypothalamic neurons, $\mathrm{Li}^{+}$increased the GABAergic synaptic activities via action potential independent presynaptic mechanisms. Next, concentration-dependent replacement of $\mathrm{Na}^{+}$by $\mathrm{Li}^{+}$in artificial cerebrospinal fluid increased frequencies of GABAergic miniature inhibitory postsynaptic currents without altering their amplitudes. $\mathrm{Li}^{+}$perfusion induced inward currents in the majority of hypothalamic neurons independent of amino-acids receptor activation. These results suggests that $\mathrm{Li}^{+}$treatment can directly affect the hypothalamic region of the brain and regulate the release of various neurohormones involved in synchronizing the neuroendocrine axis.
\end{abstract}

Keywords: lithium; hypothalamic preoptic area neurons; GABAergic neurotransmission; patchclamp; neuroendocrine axis

\section{Introduction}

Gamma-aminobutyric acid (GABA) is well known to be a major inhibitory neurotransmitter in the central nervous system (CNS) [1]. Excitation and inhibition of neuronal activities in the CNS are balanced by GABAergic transmission, whose impairment can result in various CNS disorders [2,3]. Various physiological and pathological conditions continuously modulate the strength and polarity of GABAergic transmission in the CNS [4]. The hypothalamic area of the CNS contains GABAergic and glutamatergic neurons and their receptors that regulate various hypothalamic functions such as the release of neurohormones, control circadian activities [5]. Additionally, some hypothalamus areas receive GABAergic and glycinergic innervations from other brain areas [6-8].

In the hypothalamic preoptic area (hPOA), GABA and glutamate mediate most of the fast postsynaptic potentials/events, indicating that neuronal communications in the hypothalamic area are due to amino acid neurotransmitters [9]. GABA in the hypothalamic area exerts multiple effects on the hypothalamic-pituitary system. It is involved in the physiological control of anterior pituitary hormones [10], and regulation of the neuroendocrine system [6]. The hPOA is critically involved in several homeostatic processes such as sleep, reproduction, osmolality, body temperature, and behavior process as most brain regions have interconnections to the hPOA [11].

Lithium-ion $\left(\mathrm{Li}^{+}\right)$is known to exhibit a therapeutic effect in the treatment of some neurological disorders such as Parkinson's diseases, Alzheimer's diseases, and bipolar 
disorder [12,13]. Neurotransmitters such as GABA, glutamate, dopamine, glycine, and acetylcholine are modulated by lithium [13]. It has been reported that $\mathrm{Li}^{+}$suppresses dopamine and glutamate transmissions but increases GABA neurotransmission at the neuronal level [14]. For example, granule cells (GCs) in the hippocampal dentate gyrus show increased GABAergic synaptic inputs to GCs by lithium [15]. Besides, $\mathrm{Li}^{+}$can act on the second-messenger system at the intracellular and molecular level, thus, regulating neurotransmission [14].

Both in vivo and in vitro studies have suggested that $\mathrm{Li}^{+}$can alter the release of several hormones such as prolactin, growth hormone [16], corticotropin-releasing hormone [17], arginine vasopressin [18], and opioid peptides like $\beta$-endorphin, dynorphin, and metenkephalin from the hypothalamus [19]. Furthermore, $\mathrm{Li}^{+}$can suppress the secretion of gonadotropins and gonadal hormones [20], decrease testosterone levels in male rats, and increase estrogen levels in female rats [21]. Several clinical cases have reported that $\mathrm{Li}^{+}$can impact hypothalamic-pituitary-adrenal (HPA) [22,23], hypothalamic-pituitarythyroid (HPT) [24], and hypothalamic-pituitary-gonadal (HPG) [25] axes. However, the effect of $\mathrm{Li}^{+}$on hypothalamic neuronal excitability and the precise action mechanism involved in such an effect have not been fully understood yet. Therefore, the objective of this study was to investigate $\mathrm{Li}^{+}$action on hypothalamic neurons using the whole-cell patch-clamp technique.

\section{Results}

\section{1. $\mathrm{Li}^{+}$Enhances the Frequency of Spontaneous Inhibitory Postsynaptic Currents (sIPSCs)}

sIPSCs were recorded from hPOA neurons in the presence of ionotropic glutamate receptor blockers CNQX and AP5. Mean frequency and amplitude of sIPSCs under normal artifical cerebrospinal fluid (ACSF) conditions were $3.02 \pm 1.04 \mathrm{~Hz}(n=10)$ and $80.5 \pm 12.6 \mathrm{pA}(n=10)$, respectively. In the same neuron, perfusion of $\mathrm{LiCl}$ ACSF rapidly and reversibly increased the frequency of sIPSCs. Mean frequency and amplitude of sIPSCs in hPOA neurons during $\mathrm{Li}^{+}$ACSF exposure were $7.05 \pm 1.91 \mathrm{~Hz}(n=10)$ and $73.9 \pm 12.1 \mathrm{pA}(n=10)$, respectively (Figure 1A). The time-frequency histogram showed an immediate and reversible increase in the frequency of sIPSCs by Li+ (Figure 1B). The cumulative probability curve (Figure 1C) showed a progressive leftward shift in the inter-event interval (IEI) of sIPSCs events shown in Figure 1A. The frequency of sIPSCs was significantly increased by $\mathrm{Li}^{+}$application (relative frequency compared to control: $3.08 \pm 0.72$, $n=10, p<0.01$ ). However, the amplitude of sPSCs was not affected by $\mathrm{Li}^{+}$(relative amplitude: $1.01 \pm 0.17, n=10, p>0.05$ ) (Figure 1D).

\section{2. $\mathrm{Li}^{+}$Enhances the Frequency of Miniature Inhibitory Postsynaptic Currents (mIPSCs)}

To determine if $\mathrm{Li}^{+}$ion could affect action potential-independent release of an inhibitory neurotransmitter from presynaptic axon terminal, mIPSCs were recorded in the presence of tetrodotoxin (TTX, a voltage-gated $\mathrm{Na}^{+}$channel blocker) and ionotropic glutamate receptor blockers CNQX and AP5. The frequency of mIPSCs was increased by $\mathrm{Li}^{+}$ACSF application in all tested neurons, as shown in Figure 2A. Mean frequency and amplitude of mIPSCs under a normal ACSF condition were $1.94 \pm 0.42 \mathrm{~Hz}(n=8)$ and $57.1 \pm 10.5 \mathrm{pA}(n=8)$, respectively. In the presence of $\mathrm{Li}^{+} \mathrm{ACSF}$, mean frequency and amplitude of mIPSCs in hPOA neurons were $4.44 \pm 1.29 \mathrm{~Hz}(n=8)$ and $57.2 \pm 9.59 \mathrm{pA}$ $(n=8)$, respectively. Time-frequency histogram of mIPSCs showed an increase in the frequency on $\mathrm{Li}^{+}$exposure (Figure $2 \mathrm{~B}$ ). $\mathrm{Li}^{+}$significantly shifted the cumulative frequency curve to the left (Figure 2C). The frequency of mIPSCs was significantly increased by $\mathrm{Li}^{+}$ application (relative frequency compared to control: $2.04 \pm 0.24, n=8, p<0.01$ ). However, the amplitude of sPSCs was not affected by $\mathrm{Li}^{+}$(relative amplitude: $1.05 \pm 0.09, n=8$, $p>0.05$ ) (Figure 2D). 
A

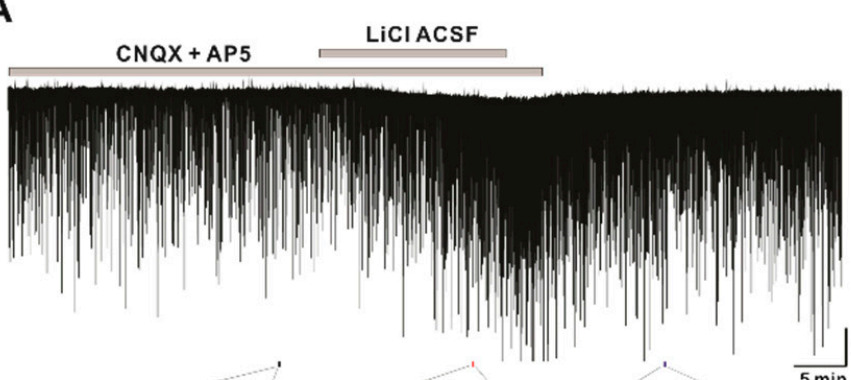

B

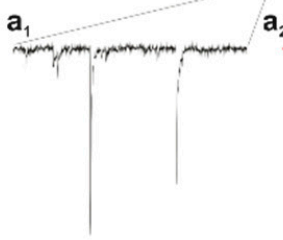

$a_{2}$

$\mathbf{a}_{3}$
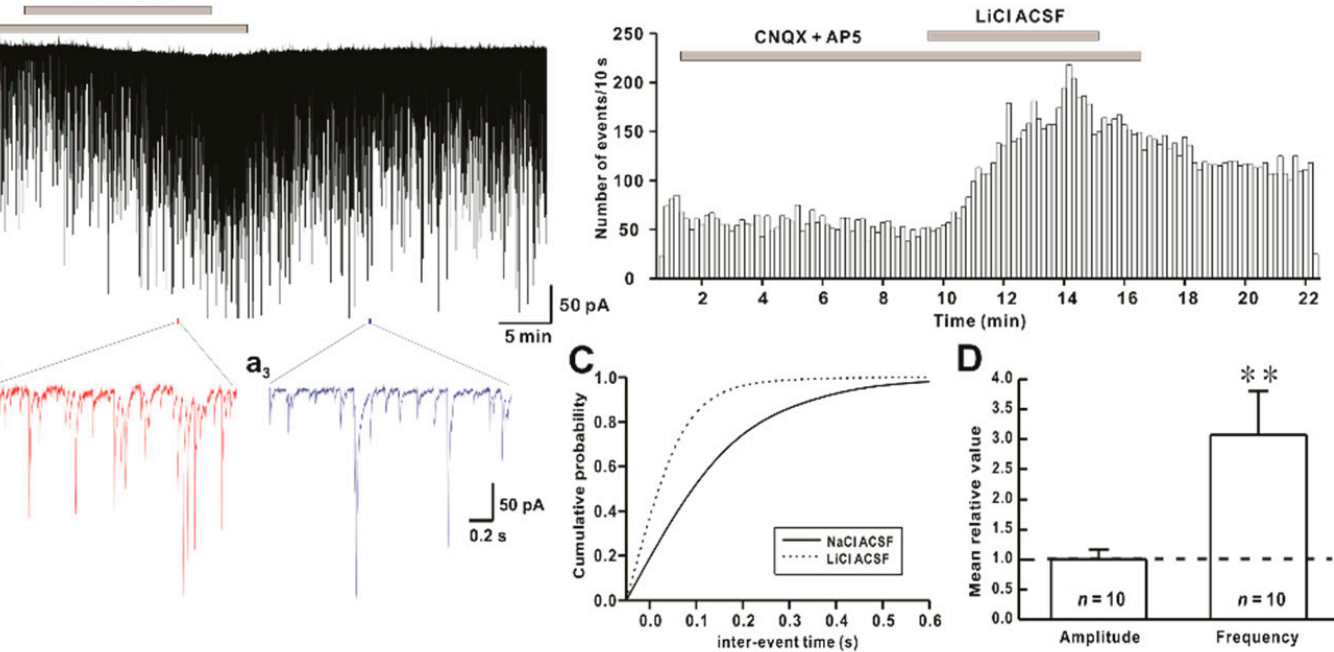

Figure 1. Effect of $\mathrm{Li}^{+}(126 \mathrm{mM})$ on spontaneous inhibitory postsynaptic currents (sIPSCs) on hypothalamic preoptic area (hPOA) neurons. (A) A representative current trace of sIPSCs recorded in the presence of $\mathrm{Na}^{+}$and $\mathrm{Li}^{+}$artifical cerebrospinal fluid (ACSF) on hPOA neurons at a holding potential of $-60 \mathrm{mV}$. ( $\left.\mathbf{a}_{1}-\mathbf{a}_{3}\right)$, sections of the current trace in Figure 1A show sIPSC before, during, and after perfusion of $\mathrm{Li}^{+}$at $2 \mathrm{~s}$ intervals, respectively. (B) A spike frequency histogram (bin size $10 \mathrm{~s}$ ) of current traces in Figure 1A. (C) A cumulative probability plot of sIPSCs inter-event interval (IEI) in the presence of $\mathrm{Na}^{+}$ (solid line) and $\mathrm{Li}^{+}$(dotted line). Note that the cumulative probability curve was left-shifted by $\mathrm{Li}^{+}$, indicating the increase of sIPSCs frequency (Kolmogorov-Smirnov test, $p<0.05$ ). (D) Mean relative amplitude and frequency of sIPSCs in LiCl ACSF compared to $\mathrm{NaCl} \operatorname{ACSF}(* * p<0.01$ by a paired $t$-test).

A

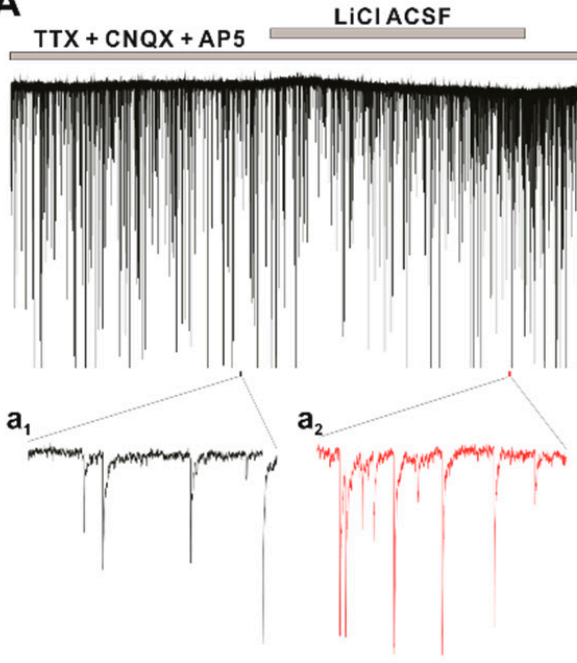

B

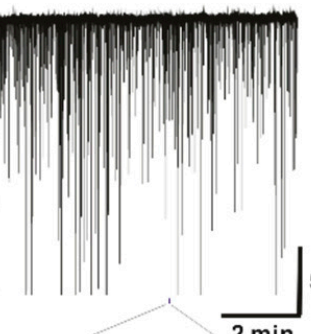

\begin{abstract}
$\mathbf{a}_{3}$
\end{abstract}

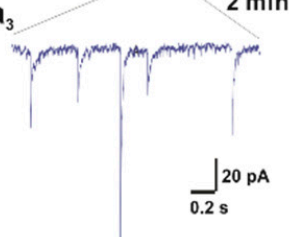

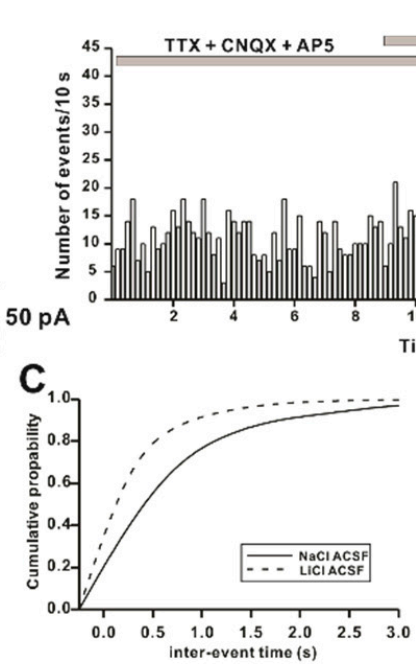

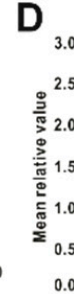

LiCIACSF
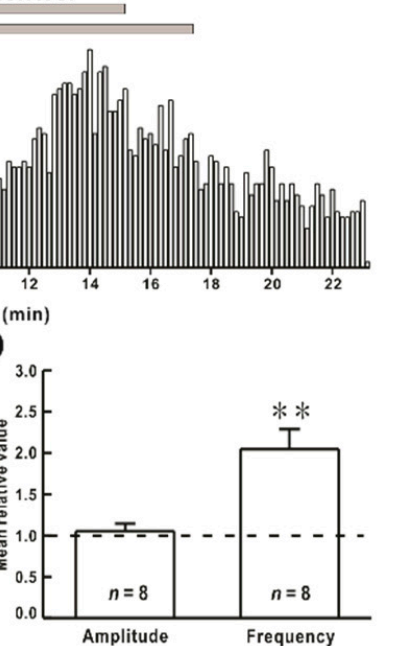

Figure 2. Effect of $\mathrm{Li}^{+}$on miniature inhibitory postsynaptic currents (mIPSCs) on hPOA neurons. (A) A representative current trace of mIPSCs recorded in the presence of $\mathrm{Na}^{+}$and $\mathrm{Li}^{+}$ACSF on hPOA neurons at a holding potential of $-60 \mathrm{mV}$. $\left(\mathbf{a}_{1}-\mathbf{a}_{3}\right)$, sections of the current trace in Figure 2A show mIPSCs before, during, and after perfusion of $\mathrm{Li}^{+}$at 2-s intervals, respectively. (B) A spike frequency histogram of the current trace in Figure 2A. (C) A cumulative probability plot of mIPSCs inter-event interval (IEI) in the presence of $\mathrm{Na}^{+}$(solid line) and $\mathrm{Li}^{+}$(dotted line). Note that the cumulative probability curve was left-shifted by $\mathrm{Li}^{+}$, indicating the increase of mIPSCs frequency (Kolmogorov-Smirnov test, $p<0.05$ ). (D) Mean relative amplitude and frequency of mIPSCs in $\mathrm{LiCl}$ ACSF compared to $\mathrm{NaCl} \mathrm{ACSF}$ (** $p<0.01$ by paired $t$-test). 


\section{3. $\mathrm{Li}^{+}$Increases the Frequency of GABAergic mIPSCs on hPOA Neurons}

In the CNS, GABAergic and glycinergic neurotransmissions are the major inhibitory inputs in neuronal regulation. The pre-optic area contains GABAergic neurons [26] and receives glycinergic intervention from a different region of the brain $[7,8]$. To determine whether GABA release might be involved in the increase of mIPSCs frequency by $\mathrm{Li}^{+}$, mIPSCs were recorded in the presence of strychnine, a glycine receptor antagonist. Mean frequency and amplitude of GABAergic mIPSCs under normal ACSF condition were $1.90 \pm 0.41 \mathrm{~Hz}(n=7)$ and $44.7 \pm 7.7 \mathrm{pA}(n=7)$, respectively. The mean frequency of GABAergic mIPSCs in the presence of strychnine was increased to $3.65 \pm 0.61 \mathrm{~Hz}(n=7)$ by $\mathrm{Li}^{+}$. However, the mean amplitude was not changed ( $\left.38.1 \pm 5.03 \mathrm{pA}, n=7\right)$, (Figure 3A). The time-frequency histogram showed an immediate and reversible increase in the event of GABAergic mIPSCs in the presence of $\mathrm{Li}^{+}$ACSF (Figure 3B). In the cumulative probability plot, the IEI of the GABAergic mIPSCs was shifted to the left, as shown in Figure 3A, indicating an increase in the frequency of GABAergic mIPSCs (Figure 3C). The frequency of GABAergic mIPSCs was significantly increased by $\mathrm{Li}^{+}$application (relative frequency compared to control: $2.1 \pm 0.22, n=7, p<0.01$ ). However, the amplitude of sPSCs was not affected by $\mathrm{Li}^{+}$(relative amplitude: $0.9 \pm 0.06, n=7, p>0.05$ ) (Figure 3D).

A

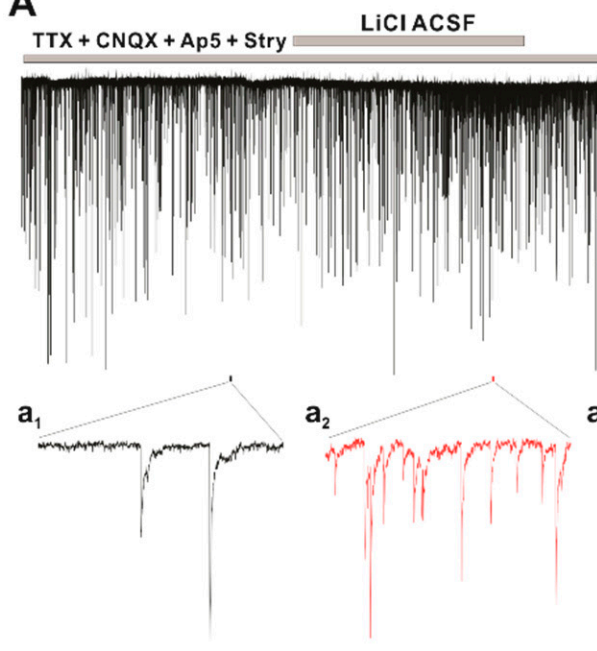

B
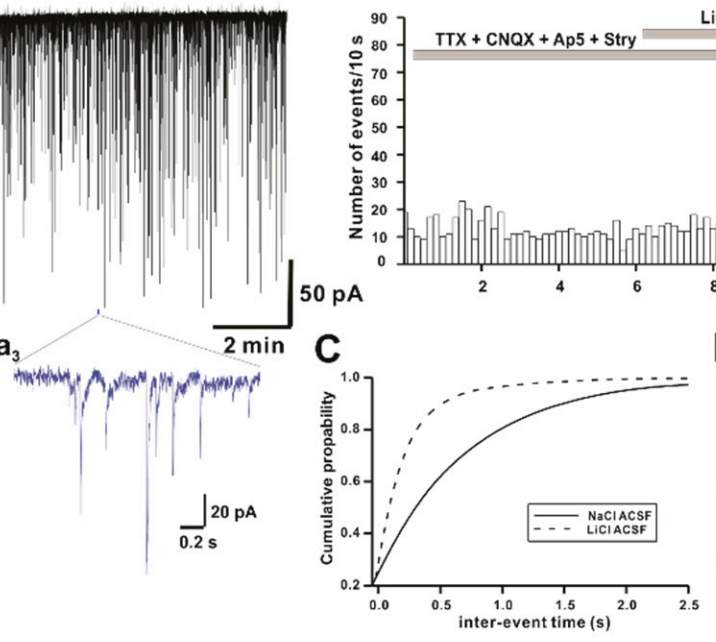

LCIACSF
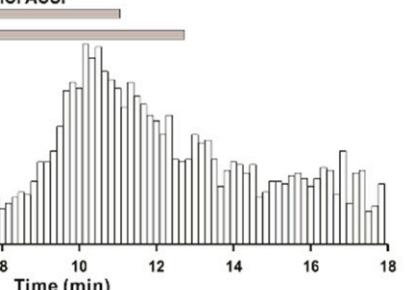

D

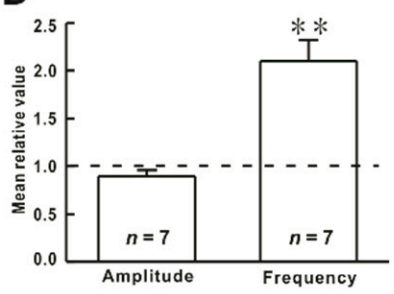

Figure 3. Effect of $\mathrm{Li}^{+}$on GABAergic mIPSCs on hPOA neurons. (A) A representative current trace of GABAergic mIPSCs recorded in the presence of $\mathrm{Na}^{+}$and $\mathrm{Li}^{+} \mathrm{ACSF}$ on hPOA neuron. $\left(\mathbf{a}_{1}-\mathbf{a}_{3}\right)$, sections of the current trace in Figure $3 \mathrm{~A}$ show GABAergic mIPSCs before, during, and after perfusion of $\mathrm{Li}^{+}$at 2-s intervals, respectively. (B) A spike frequency histogram of the trace in Figure 3A. (C) A cumulative probability plot of GABAergic mIPSCs inter-event interval (IEI) in the presence of $\mathrm{Na}^{+}$(solid line) and $\mathrm{Li}^{+}$(dotted line). Note that the cumulative probability curve was left-shifted by $\mathrm{Li}^{+}$, indicating the increase of GABAergic mIPSCs frequency (Kolmogorov-Smirnov test, $p<0.05$ ). (D) Mean relative amplitude and frequency of GABAergic mIPSCs in LiCl ACSF compared to NaCl ACSF (** $p<0.01$ by paired $t$-test).

Furthermore, the concentration-dependent replacement of $\mathrm{Na}^{+}$ions with $\mathrm{Li}^{+}$ions in the ACSF solution augmented the frequency of GABAergic mIPSCs in a concentrationdependent manner without affecting the amplitude, as shown in Figure 4.

\section{4. $\mathrm{Li}^{+}$Perfusion Induces Repeatable Inward Currents on hPOA Neurons}

In addition to the effect of $\mathrm{Li}^{+}$in postsynaptic currents, we observed a change in holding current on $\mathrm{Li}^{+}$perfusion. In the whole-cell voltage-clamp experiment, a reversible inward current of magnitude $(-21.6 \pm 4.6 \mathrm{pA}, n=14)$ was observed in 14 of 18 neurons tested during $\mathrm{Li}^{+}$ACSF perfusion. With successive application of $\mathrm{LiCl}$ ACSF, there was no significant difference in inward current induced during the first and second applications (Figure 5A). The mean amplitude of inward current $(-22.0 \pm 1.40 \mathrm{pA}, n=5)$ induced by 
the first application of $\mathrm{LiCl}$ ACSF was similar to that induced by the second application $(-22.8 \pm 2.1 \mathrm{pA}, n=5, p>0.05)$ (Figure 5B). This indicated that $\mathrm{Li}^{+}$induced a repeatable and non-desensitized response on $\mathrm{hPOA}$ neurons during the successive perfusion.

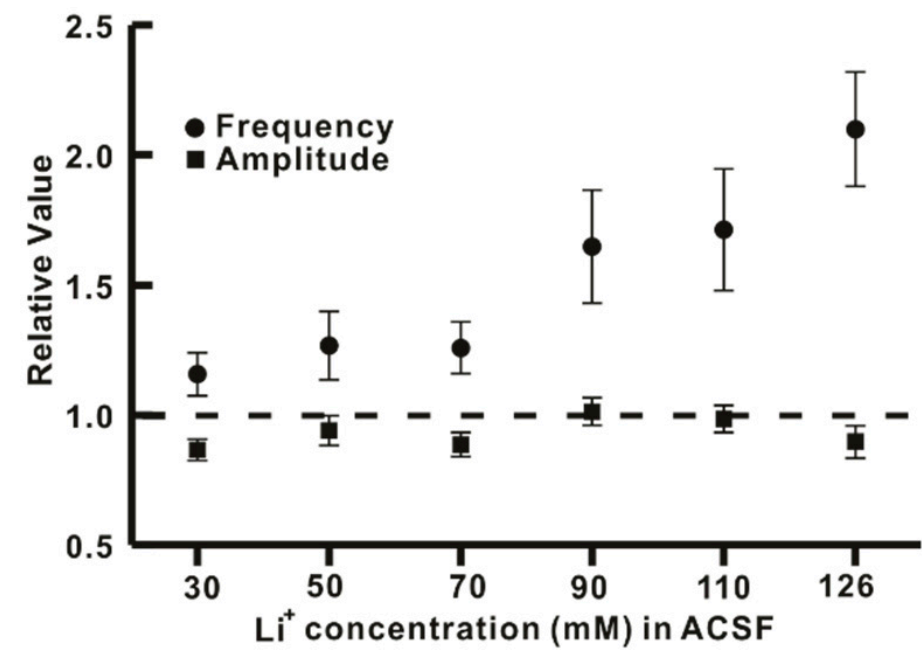

Figure 4. Concentration-dependent effect of $\mathrm{Li}^{+}$on GABAergic mIPSCs. The graph shows a concentration-dependent increase in GABAergic mIPSCs frequency by $\mathrm{Li}^{+}$without affecting the amplitude.

A

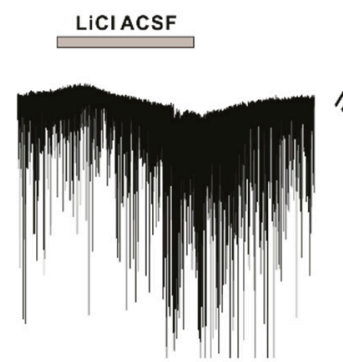

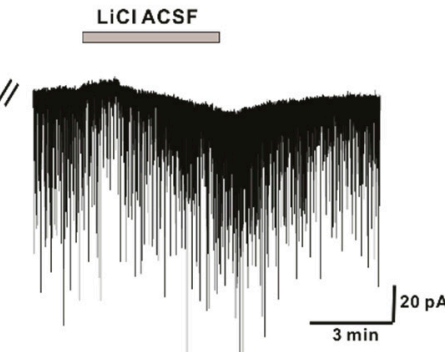

B

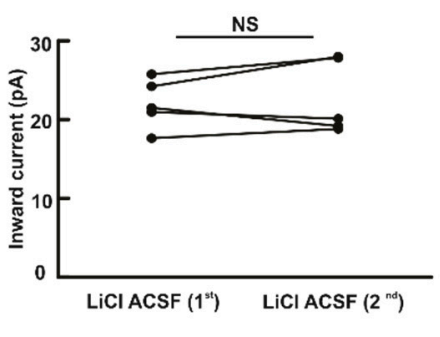

Figure 5. $\mathrm{Li}^{+}$induces repeatable inward currents on hPOA neurons. (A) A representative current trace showing repeatable inward currents on hPOA neuron induced by perfusion of LiCl ACSF. (B) Before and after plot shows no significant difference in the mean inward currents between the first and the second perfusion of $\operatorname{LiCl} \operatorname{ACSF}(n=5, p>0.05$ by paired $t$-test). NS, not significant.

\section{5. $\mathrm{Li}^{+}$Directly Acts on hPOA Neurons and Its Action Is Independent of Amino-Acid Receptors}

Next, we attempted to explore the direct action of $\mathrm{Li}^{+}$ions on $\mathrm{hPOA}$ neurons. Neurons in the preoptic area can generate currents due to activation of $\mathrm{GABA}_{\mathrm{A}}$, glycine, or ionotropic glutamate receptors $[27,28]$. Therefore, inward current induced by $\mathrm{Li}^{+}$was recorded in the presence of blocking mixture $(\mathrm{BM})$ including TTX $(0.5 \mu \mathrm{M})$, picrotoxin $\left(\mathrm{GABA}_{\mathrm{A}}\right.$ receptor antagonist, $50 \mu \mathrm{M}$ ), CNQX (non-NMDA glutamate receptor antagonist, $10 \mu \mathrm{M}$ ), AP5 (NMDA glutamate receptor antagonist, $20 \mu \mathrm{M}$ ), and strychnine (glycine receptor antagonist, $2 \mu \mathrm{M})$. In the presence of BM, the inward current induced by LiCl ACSF was maintained (Figure 6A). There was a similarity in the mean amplitude of inward current induced by $\mathrm{Li}^{+}$alone $(-24.3 \pm 3.21 \mathrm{pA}, n=6)$ and $\mathrm{Li}^{+}$in the presence of $\mathrm{BM}(-26.6 \pm 4.8 \mathrm{pA}, n=6$, $p>0.05$ ) (Figure 6B), indicating $\mathrm{Li}^{+}$directly acts on the post-synaptic hPOA neurons and such responses on hPOA are not due to the activation of $\mathrm{GABA}_{\mathrm{A}}$, glycine, or ionotropic glutamate receptors. 
A

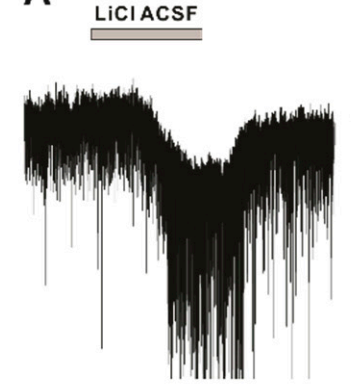

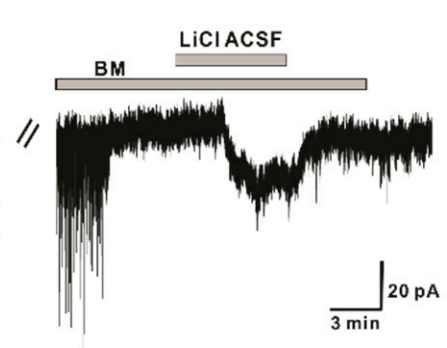

B

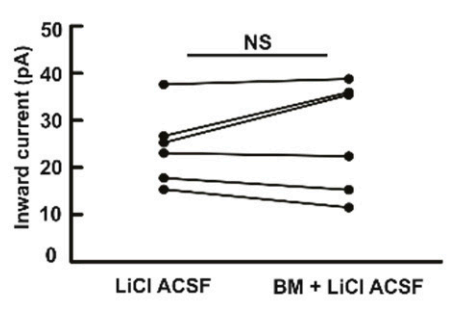

Figure 6. $\mathrm{Li}^{+}$acts on postsynaptic hPOA neurons. (A) A representative current trace showing inward currents induced upon perfusion of $\mathrm{LiCl}$ ACSF. $\mathrm{Li}^{+}$induced inward current persisted in the presence of BM (blocking mixture), including TTX $\left(\mathrm{Na}^{+}\right.$channel blocker), picrotoxin $\left(\mathrm{GABA}_{\mathrm{A}}\right.$ receptor blocker), strychnine (glycine receptor blocker), CNQX (non-NMDA glutamate receptor antagonist), and AP5 (NMDA receptor antagonist). (B) The before and after plot shows no significant difference in the mean inward current between $\mathrm{Li}^{+}$alone and $\mathrm{Li}^{+}$in the presence of blocking mixture ( $n=6, p>0.05$ by the paired $t$-test). NS, not significant.

\section{Discussion}

Results of this study showed that $\mathrm{Li}^{+}$increased GABAergic synaptic activities in hypothalamic preoptic area neurons by action potential independent presynaptic mechanisms as TTX (a voltage-gated $\mathrm{Na}^{+}$channel blocker) did not affect the frequency of spontaneous inhibitory postsynaptic currents (sIPSCs) increased by $\mathrm{Li}^{+}$. Besides, $\mathrm{Li}^{+}$perfusion induced inward current for the majority of hPOA neurons. These findings are consistent with previous studies, showing that $\mathrm{Li}^{+}$administration can alter the resting potential $[29,30]$, and enhance GABAergic activities [15].

In the hypothalamic preoptic area, about 70 neuronal populations have been identified with inhibitory neurons being the most abundant [31]. GABAergic and glutamatergic neurotransmissions are the major inputs for neuronal regulation in the hypothalamus [32,33]. Besides, this region has interconnections to various brain areas [11] and receives glycinergic innervation $[7,8]$. GABA and glycine are major inhibitory transmitters whereas glutamate is the major excitatory transmitter in CNS. Electrophysiological experiments have revealed both excitatory and inhibitory effects of $\mathrm{Li}^{+}$on neuronal excitability $[15,29,34]$.

In electrophysiology, complete or partial replacement of $\mathrm{Na}^{+}$by $\mathrm{Li}^{+}$in the external medium could modulate neuronal properties and a neurotransmitter system. For example, $\mathrm{Li}^{+}$induced depolarization and altered the frequency and shape of the action potential in mitral cells [29]. Similarly, both excitatory and inhibitory synaptic transmission were enhanced by $\mathrm{Li}^{+}$perfusion $[15,35,36]$. Furthermore, chronic lithium administration resulted in a significant change of the brain neurotransmitter system of selected brain regions [37]. At the neuronal level, $\mathrm{Li}^{+}$exhibited both pre-synaptic and post-synaptic action to modulate neurotransmission mediated by dopamine, GABA, glutamate, and serotonin $[14,38] . \mathrm{Li}^{+}$ induced a change in the GABAergic system and GABA receptors have been well documented in various areas of CNS, such as corpus striatum [37], prefrontal cortex [39], hypothalamus [37,40], and dentate gyrus [15].

Findings of the present study suggest that the replacement of $\mathrm{Na}^{+}$by $\mathrm{Li}^{+}$in ACSF could rapidly increase the frequency of synaptic activities without altering their amplitudes. In addition, there was no significant difference between the increased ratio of sIPSCs and mIPSCs frequency induced by $\mathrm{Li}^{+}$, indicating that $\mathrm{Li}^{+}$enhanced the action potential-independent presynaptic mechanism mediated GABAergic synaptic events. However, Lee et al. have observed that exposure to $\mathrm{Li}^{+}(25 \mathrm{mM})$ could enhance GABAergic synaptic activities by AP-dependent and AP-independent presynaptic mechanisms in hippocampal slices [15]. Our results also revealed that concentration-dependent replacement of $\mathrm{Na}^{+}$by $\mathrm{Li}^{+}$in ACSF increased frequencies of GABAergic mIPSCs without affecting their amplitudes. 
In addition to the presynaptic effect, the postsynaptic effect of $\mathrm{Li}^{+}$on neuronal regulation has been reported in various neuronal groups [29,41,42]. Replacement of $\mathrm{Na}^{+}$with $\mathrm{Li}^{+}$ can induce depolarization in cortical neurons [29], giant neurons [41], CA1 neurons [43], spinal motoneurons, and olfactory cortex [42]. Similarly, we observed an inward current when $\mathrm{LiCl}$ ACSF perfusion was performed. $\mathrm{Li}^{+}$induced non-desensitizing repeatable inward currents. Such responses were preserved in the presence of tetrodotoxin (TTX, a voltage-gated $\mathrm{Na}^{+}$channel blocker) and blocker for amino acid receptors. Previous findings have suggested that $\mathrm{Li}^{+}$can replace $\mathrm{Na}^{+}$ions and pass through neuronal membranes along $\mathrm{Na}^{+}$channels $[29,41,44]$. In addition, $\mathrm{Li}^{+}$can interact with electrogenic $\mathrm{Na}^{+} / \mathrm{K}^{+}$pumps as three action sites for $\mathrm{Li}^{+}$interaction has been identified [42]. To induce membrane depolarization, $\mathrm{Li}^{+}$might suppress the activity of an electrogenic $\mathrm{Na}^{+}$pump, reduce the intracellular $\mathrm{K}^{+}$concentration, and increase the release of an excitatory transmitter $[42,45,46]$. Grafe et.al have demonstrated that $\mathrm{Li}^{+}$can induce a shift of the $\mathrm{K}^{+}$equilibrium potential responsible for membrane depolarization of neurons [42]. In the present study, we observed that $\mathrm{Li}^{+}$directly acted on hPOA neurons independent of voltage-gated $\mathrm{Na}^{+}$channels, $\mathrm{GABA}_{\mathrm{A}}$, glycine, or ionotropic glutamate receptors. However, we could not elucidate the complete mechanism responsible for the induced inward current.

Neurotransmission disturbances have been reported in several neurological disorders $[47,48]$, and lithium salt is widely used as a therapeutic agent for treating neurological and psychiatric disorders $[49,50]$. The therapeutic mechanism of $\mathrm{Li}^{+}$involves its neuroprotective effect, neurotropic effect, and neuronal plasticity [13,51]. Lithium exhibits a neuroprotective effect by modulating glutamatergic transmission and inhibiting $\mathrm{N}$-methyl-D-aspartate (NMDA) receptor-mediated calcium influx induced excitotoxicity $[52,53]$. Besides, $\mathrm{Li}^{+}$can regulate synaptic plasticity by suppressing $\alpha$-amino-3-hydroxy5-methyl-4-isoxazolepropionic acid (AMPA) glutamate receptor trafficking [54]. Despite its therapeutic effects on neurological and psychiatric disorders, it can disturb the neuroendocrine axis, mainly in hypothalamic-pituitary-thyroid, hypothalamic-pituitary-gonadal, and hypothalamic-pituitary-adrenal axis in patients under lithium therapy [55,56]. Besides, oral lithium administration can result in $\mathrm{Li}^{+}$accumulation in central neuroendocrine tissues, such as the hypothalamus and pituitary gland [57]. Furthermore, our electrophysiological data showed an increase in GABAergic neurotransmission across the hypothalamic preoptic area upon lithium exposure. This indicates that $\mathrm{Li}^{+}$treatment might directly affect the hypothalamic region of the brain and regulate the release of various neurohormones involved in synchronizing the neuroendocrine axis. However, the mechanism behind the induced inward current on hPOA neurons upon $\mathrm{Li}^{+}$perfusion warrants further investigation.

It has been reported that lithium and anti-epileptic drugs showed side effects on the endocrine system. Alteration in the endocrine system might lead to endocrine complications and related health problems. Theses complications may arise from altered neurotransmission in the hypothalamus. Using the electrophysiology approach, we showed that GABAergic activity was increased across hypothalamic neurons upon $\mathrm{Li}^{+}$exposure, explaining the cause for the disruption in the neuroendocrine axis in patients receiving lithium therapy.

\section{Materials and Methods}

\subsection{Animals}

Electrophysiological experiments were performed using brain slices prepared from immature mice (postnatal day 10 to 25 ) housed under $12 \mathrm{~h} \mathrm{light} / 12 \mathrm{~h}$ dark cycle (lights on at 07:00 AM) with free access to food and water. All animal care conditions and experiments were approved by the Institutional Animal Care and Use Committee of Jeonbuk National University with approval number of CBNU-2018-071 (4 September 2018) and CBNU-2019089 (14 November 2019). 


\subsection{Brain Slice Preparation}

Mice were decapitated. Their brains were promptly excised [28] and immersed in ice-cold artificial cerebrospinal fluid (ACSF) with the following compositions (in $\mathrm{mM}$ ): $126 \mathrm{NaCl}, 2.5 \mathrm{KCl}, 2.4 \mathrm{CaCl}_{2}, 1.2 \mathrm{MgCl}_{2}, 11 \mathrm{D}$-glucose, $1.4 \mathrm{NaH}_{2} \mathrm{PO}_{4}$, and $25 \mathrm{NaHCO}_{3}$ (pH 7.4 when bubbled with $95 \% \mathrm{O}_{2}$ and $5 \% \mathrm{CO}_{2}$ ). Coronal brain slices (230 to $300 \mu \mathrm{m}$ ) containing a hypothalamic preoptic area were obtained with a vibratome (VT1200S, Leica biosystems, Wetzlar, Germany) in ice-cold ACSF. These slices were stored in oxygenated ACSF for at least $1 \mathrm{~h}$ at room temperature before electrophysiological recording. Various concentrations of $\mathrm{LiCl}$ ACSF were prepared by replacing $\mathrm{NaCl}$ iso-osmotically with $\mathrm{LiCl}$.

\subsection{Whole-Cell Patch-Clamp Recording and Data Analysis}

Coronal brain slices were transferred to the recording chamber, entirely submerged, and continuously perfused with oxygenated ACSF at a flow rate of 4 to $5 \mathrm{~mL} / \mathrm{min}$. Neurons located in the hypothalamic preoptic area were targeted visually with an upright microscope (BX51W1, Olympus, Tokyo, Japan) equipped with Nomarski differential interference contrast optics. Patch pipettes were prepared from thin-wall borosilicate capillary glass (PG52151-4; WPI, Sarasota, FL, USA) using a Flaming/Brown puller (P-97, Sutter Instruments Co., Novato, CA USA). Patch pipettes were filled with an internal solution containing (in mM): $140 \mathrm{KCl}, 1 \mathrm{CaCl}_{2}, 1 \mathrm{MgCl}_{2}, 10$ HEPES, 4 MgATP, and 10 EGTA (pH 7.3 with $\mathrm{KOH}$ ). Tip resistance of the loaded pipette ranged from 4 to $6 \mathrm{M} \Omega$. Electrode potential was nullified before giga-seal was achieved. Neurons were voltage-clamped at a holding of $-60 \mathrm{mV}$. These signals were sequentially amplified and filtered at $1 \mathrm{kHz}$ with an Axopatch 200B (Molecular Devices, San Jose, CA, USA) and digitized at $1 \mathrm{kHz}$ using a Digidata 1440A interface (Molecular Devices, San Jose, CA, USA). Acquisition and subsequent analysis of acquired data were performed using a Clampex 10.6 software (Molecular Devices) and an Origin 2018 software (OriginLab Corp., Northampton, MA, USA). Neurons displaying a shift in holding current $>5 \mathrm{pA}$ were considered to have responded. All recordings were made at room temperature.

Synaptic events were analyzed and counted using a Mini-Analysis program (version 6.0.7, Synaptosoft, Decatur, GA, USA). Initially, synaptic currents were screened automatically at $>10 \mathrm{pA}$ amplitude threshold and then manually accepted or rejected based on the decay time constant $(>5 \mathrm{~ms})$ and the rise time constant $(<8 \mathrm{~ms})$. The frequency and amplitude of synaptic events in a single neuron were compared using the Kolmogorov-Smirnov test. All values are provided as a mean \pm standard error of the mean. Student's paired $t$-test was used to compare relative mean amplitude and frequency between two groups. Statistical significance was considered when $p$-values were less than 0.05 . " $n$ " represents the number of neurons recorded.

\subsection{Chemicals}

Chemicals including lithium chloride $(\mathrm{LiCl})$, picrotoxin, strychnine hydrochloride (strychnine), and chemicals for ACSF were purchased from Sigma-Aldrich (St. Louis, MO, USA). Tetrodotoxin citrate (TTX), DL-AP5 (AP5), and CNQX disodium salt (CNQX) were purchased from Tocris Bioscience (Avonmouth, Bristol, UK). Stocks were diluted (usually by 1000 times) to a working concentration in ACSF before bath application.

Author Contributions: S.R. performed the experiments, analyzed the data, and wrote the draft. S.H.J. and S.J.P. contributed to reviewing and editing the draft. S.K.H. conceptualized and designed the study and completed the manuscript. All authors have read and agreed to the published version of the manuscript.

Funding: This research was supported by the Basic Research Program, through the National Research Foundation of Korea (NRF) funded by the Ministry of Education (2016R1D1A3B03932241). The funders had no role in the design, analysis, or writing of this article. 
Institutional Review Board Statement: All animal care conditions and experiments were approved by the Institutional Animal Care and Use Committee of Jeonbuk National University, CBNU-2018-071 (4 September 2018) and CBNU-2019-089 (14 November 2019).

Informed Consent Statement: Not applicable.

Conflicts of Interest: The authors declare no conflict of interest.

\section{References}

1. Watanabe, M.; Maemura, K.; Kanbara, K.; Tamayama, T.; Hayasaki, H. GABA and GABA receptors in the central nervous system and other organs. Int. Rev. Cytol. 2002, 231, 1-47.

2. Kirmse, K.; Holthoff, K. Functions of GABAergic transmission in the immature brain. e-Neuroforum 2017, 23, 27-33. [CrossRef]

3. Ramamoorthi, K.; Lin, Y. The contribution of GABAergic dysfunction to neurodevelopmental disorders. Trends Mol. Med. 2011, 17, 452-462. [CrossRef]

4. Deidda, G.; Bozarth, I.F.; Cancedda, L. Modulation of GABAergic transmission in development and neurodevelopmental disorders: Investigating physiology and pathology to gain therapeutic perspectives. Front. Cell Neurosci. 2014, 8, 119. [CrossRef]

5. Belousov, A.B.; O’Hara, B.F.; Denisova, J.V. Acetylcholine becomes the major excitatory neurotransmitter in the hypothalamus in vitro in the absence of glutamate excitation. J. Neurosci. 2001, 21, 2015-2027. [CrossRef]

6. Vincent, S.R.; Hökfelt, T.; Wu, J.Y. GABA neuron systems in hypothalamus and the pituitary gland. Neuroendocrinology 1982, 34, 117-125. [CrossRef]

7. Rampon, C.; Luppi, P.H.; Fort, P.; Peyron, C.; Jouvet, M. Distribution of glycine-immunoreactive cell bodies and fibers in the rat brain. Neuroscience 1996, 75, 737-755. [CrossRef]

8. Zeilhofer, H.U.; Studler, B.; Arabadzisz, D.; Schweizer, C.; Ahmadi, S.; Layh, B.; Bösl, M.R.; Fritschy, J.M. Glycinergic neurons expressing enhanced green fluorescent protein in bacterial artificial chromosome transgenic mice. J. Comp. Neurol. 2005, 482, 123-141. [CrossRef]

9. Hoffman, N.W.; Wuarin, J.P.; Dudek, F.E. Whole-cell recordings of spontaneous synaptic currents in medial preoptic neurons from rat hypothalamic slices: Mediation by amino acid neurotransmitters. Brain Res. 1994, 660, 349-352. [CrossRef]

10. McCann, S.M.; Vijayan, E.; Negro-Vilar, A.; Mizunuma, H.; Mangat, H. Gamma aminobutyric acid (GABA), a modulator of anterior pituitary hormone secretion by hypothalamic and pituitary action. Psychoneuroendocrinology 1984, 9, 97-106. [CrossRef]

11. Yu, S.; François, M.; Huesing, C.; Münzberg, H. The hypothalamic preoptic area and body weight control. Neuroendocrinology 2017, 106, 187-194. [CrossRef] [PubMed]

12. Mikosha, A.S.; Kovzun, O.I.; Tronko, M.D. Biological effects of lithium-fundamental and medical aspects. Ukr. Biochem. J. 2017, 89, 5-16. [CrossRef]

13. Won, E.; Kim, Y.K. An oldie but goodie: Lithium in the treatment of bipolar disorder through neuroprotective and neurotrophic mechanisms. Int. J. Mol. Sci. 2017, 18, 2679. [CrossRef]

14. Malhi, G.S.; Tanious, M.; Das, P.; Coulston, C.M.; Berk, M. Potential mechanisms of action of lithium in bipolar disorder. CNS Drugs 2013, 27, 135-153. [CrossRef] [PubMed]

15. Lee, S.H.; Sohn, J.W.; Ahn, S.C.; Park, W.S.; Ho, W.K. Li+ enhances GABAergic inputs to granule cells in the rat hippocampal dentate gyrus. Neuropharmacology 2004, 46, 638-646. [CrossRef]

16. Smythe, G.A.; Brandstater, J.F.; Lazarus, L. Acute effects of lithium on central dopamine and serotonin activity reflected by inhibition of prolactin and growth hormone secretion in the rat. Aust. J. Biol. Sci. 1979, 32, 329-334. [CrossRef]

17. Bschor, T.; Ritter, D.; Winkelmann, P.; Erbe, S.; Uhr, M.; Ising, M.; Lewitzka, U. Lithium monotherapy increases ACTH and cortisol response in the DEX/CRH test in unipolar depressed subjects. A study with 30 treatment-naive patients. PLoS ONE 2011, 6, e27613. [CrossRef]

18. Anai, H.; Ueta, Y.; Serino, R.; Nomura, M.; Kabashima, N.; Shibuya, I.; Takasugi, M.; Nakashima, Y.; Yamashita, H. Upregulation of the expression of vasopressin gene in the paraventricular and supraoptic nuclei of the lithium-induced diabetes insipidus rat. Brain Res. 1997, 772, 161-166. [CrossRef]

19. Burns, G.; Herz, A.; Nikolarakis, K. Stimulation of hypothalamic opioid peptide release by lithium is mediated by opioid autoreceptors: Evidence from a combined in vitro, ex vivo study. Neuroscience 1990, 36, 691-697. [CrossRef]

20. Sheikha, S.H.; LeGate, L.S.; Banerji, T.K. Lithium suppresses ovariectomy-induced surges in plasma gonadotropins in rats. Life Sci. 1989, 44, 1363-1369. [CrossRef]

21. Allagui, M.; Hfaiedh, N.; Croute, F.; Guermazi, F.; Vincent, C.; Soleilhavoup, J.; El, A.F. Side effects of low serum lithium concentrations on renal, thyroid, and sexual functions in male and female rats. Comptes Rendus Biol. 2005, 328, 900-911. [CrossRef]

22. Bschor, T.; Adli, M.; Baethge, C.; Eichmann, U.; Ising, M.; Uhr, M.; Modell, S.; Künzel, H.; Müller-Oerlinghausen, B.; Bauer, M. Lithium augmentation increases the ACTH and cortisol response in the combined DEX/CRH test in unipolar major depression. Neuropsychopharmacology 2002, 27, 470-478. [CrossRef]

23. Sugawara, M.; Hashimoto, K.; Hattori, T.; Takao, T.; Suemaru, S.; Ota, Z. Effects of lithium on the hypothalamo-pituitary-adrenal axis. Endocrinol. Jpn. 1988, 35, 655-663. [CrossRef] [PubMed] 
24. Lombardi, G.; Panza, N.; Biondi, B.; Di Lorenzo, L.; Lupoli, G.; Muscettola, G.; Carella, C.; Bellastella, A. Effects of lithium treatment on hypothalamic-pituitary-thyroid axis: A longitudinal study. J. Endocrinol. Investig. 1993, 16, 259-263. [CrossRef] [PubMed]

25. Kusalic, M.; Engelsmann, F. Effect of lithium maintenance treatment on hypothalamic pituitary gonadal axis in bipolar men. $J$. Psychiatry Neurosci. 1996, 21, 181-186. [PubMed]

26. Tappaz, M.L.; Brownstein, M.J.; Kopin, I.J. Glutamate decarboxylase (GAD) and $\gamma$-aminobutyric acid (GABA) in discrete nuclei of hypothalamus and substantia nigra. Brain Res. 1977, 125, 109-121. [CrossRef]

27. Bhattarai, J.P.; Park, S.J.; Chun, S.W.; Cho, D.H.; Han, S.K. Activation of synaptic and extrasynaptic glycine receptors by taurine in preoptic hypothalamic neurons. Neurosci. Lett. 2015, 608, 51-56. [CrossRef]

28. Rijal, S.; Cho, D.H.; Park, S.-A.; Jang, S.H.; Ábrahám, I.M.; Han, S.K. Melatonin Suppresses the Kainate Receptor-Mediated Excitation on Gonadotropin-Releasing Hormone Neurons in Female and Male Prepubertal Mice. Int. J. Mol. Sci. 2020, $21,5991$. [CrossRef]

29. Butler-Munro, C.; Coddington, E.J.; Shirley, C.H.; Heyward, P.M. Lithium modulates cortical excitability in vitro. Brain Res. 2010, 1352, 50-60. [CrossRef]

30. Wu, M.; Zaborszky, L.; Hajszan, T.; Van Den Pol, A.N.; Alreja, M. Hypocretin/orexin innervation and excitation of identified septohippocampal cholinergic neurons. J. Neurosci. 2004, 24, 3527-3536. [CrossRef]

31. Moffitt, J.R.; Bambah-Mukku, D.; Eichhorn, S.W.; Vaughn, E.; Shekhar, K.; Perez, J.D.; Rubinstein, N.D.; Hao, J.; Regev, A.; Dulac, C. Molecular, spatial, and functional single-cell profiling of the hypothalamic preoptic region. Science 2018, 362, 641. [CrossRef] [PubMed]

32. Decavel, C.; Van Den Pol, A.N. GABA: A dominant neurotransmitter in the hypothalamus. J. Comp. Neurol. 1990, 302, 1019-1037. [CrossRef] [PubMed]

33. Van Den Pol, A.N.; Trombley, P.Q. Glutamate neurons in hypothalamus regulate excitatory transmission. J. Neurosci. 1993, 13, 2829-2836. [CrossRef] [PubMed]

34. Lacaille, J.C.; Cloutier, S.; Reader, T.A. Lithium reduced synaptic transmisson and increased neuronal excitability without altering endogenous serotonin, norepinephrine and dopamine in rat hippocampal slices in vitro. Prog. Neuropsychopharmacol. Biol. Psychiatry 1992, 3, 397-412. [CrossRef]

35. Higashitani, Y.; Kudo, Y.; Ogura, A.; Kato, H. Acute effects of lithium on synaptic transmission in rat hippocampus studied in vitro. Biol. Psychiatry 1990, 27, 174-182. [CrossRef]

36. Valentín, A.; García-Seoane, J.J.; Colino, A. Lithium enhances synaptic transmission in neonatal rat hippocampus. Neuroscience 1997, 78, 385-391. [CrossRef]

37. Maggi, A.; Enna, S. Regional alterations in rat brain neurotransmitter systems following chronic lithium treatment. J. Neurochem. 1980, 34, 888-892. [CrossRef]

38. Tanimoto, K.; Maeda, K.; Terada, T. Inhibitory effect of lithium on neuroleptic and serotonin receptors in rat brain. Brain Res. 1983, 265, 148-151. [CrossRef]

39. Antonelli, T.; Ferioli, V.; Lo Gallo, G.; Tomasini, M.C.; Fernandez, M.; O’Connor, W.T.; Glennon, J.C.; Tanganelli, S.; Ferraro, L. Differential effects of acute and short-term lithium administration on dialysate glutamate and GABA levels in the frontal cortex of the conscious rat. Synapse 2000, 38, 355-362. [CrossRef]

40. Gottesfeld, Z.; Ebstein, B.S.; Samuel, D. Effect of lithium on concentrations of glutamate and GABA levels in amygdala and hypothalamus of rat. Nat. New Biol. 1971, 234, 124-125. [CrossRef]

41. Akoev, G.; Sizaya, N. Influence of lithium ions on the electrical activity of nerve cells of the leech. Neurophysiology 1970, 2, 484-489. [CrossRef]

42. Grafe, P.; Reddy, M.; Emmert, H.; Ten Bruggencate, G. Effects of lithium on electrical activity and potassium ion distribution in the vertebrate central nervous system. Brain Res. 1983, 279, 65-76. [CrossRef]

43. Liu, X.; Leung, L.S. Sodium-activated potassium conductance participates in the depolarizing afterpotential following a single action potential in rat hippocampal CA1 pyramidal cells. Brain Res. 2004, 1023, 185-192. [CrossRef]

44. Janka, Z.; Jones, D. Lithium entry into neural cells via sodium channels: A morphometric approach. Neuroscience 1982, 7, 2849-2857. [CrossRef]

45. Obara, S.; Grundfest, H. Effects of lithium on different membrane components of crayfish stretch receptor neurons. J. Gen. Physiol. 1968, 51, 635-654. [CrossRef] [PubMed]

46. Giacobini, E.; Hovmark, S.; Stepita-Klauco, M. Studies on the Mechanism of Action of Lithium Ions: II. Potassium Sensitive Influx of Lithium Ions into the Crayfish Stretch Receptor Neuron Determined by Microflamephotometry. Acta Physiol. Scand. 1970, 80, 528-532. [CrossRef]

47. Leite, J.A.; Orellana, A.M.M.; Kinoshita, P.F.; de Mello, N.P.; Scavone, C.; Kawamoto, E.M. Neuroinflammation and Neurotransmission Mechanisms Involved in Neuropsychiatric Disorders. In Mechanisms of Neuroinflammation; IntechOpen: London, UK, 2017.

48. Sheffler, Z.M.; Reddy, V.; Pillarisetty, L.S. Physiology, Neurotransmitters; StatPearls Publishing: Treasure Island, FL, USA, 2020.

49. Forlenza, O.V.; De-Paula, V.J.R.; Diniz, B.S.O. Neuroprotective effects of lithium: Implications for the treatment of Alzheimer's disease and related neurodegenerative disorders. ACS Chem. Neurosci. 2014, 5, 443-450. [CrossRef] [PubMed]

50. Maletzky, B.M.; Shore, J.H. Lithium treatment for psychiatric disorders. West. J. Med. 1978, 128, 488-498. 
51. Segal, J. Lithium-an update on the mechanisms of action. Part two: Neural effects and neuroanatomical substrate. Afr. J. Psychiatry 2004, 7, 18-24. [CrossRef]

52. Shibuya-Tayoshi, S.; Tayoshi, S.Y.; Sumitani, S.; Ueno, S.; Harada, M.; Ohmori, T. Lithium effects on brain glutamatergic and GABAergic systems of healthy volunteers as measured by proton magnetic resonance spectroscopy. Prog. Neuropsychopharmacol. Biol. Psychiatry 2008, 32, 249-256. [CrossRef]

53. Nonaka, S.; Hough, C.J.; Chuang, D.M. Chronic lithium treatment robustly protects neurons in the central nervous system against excitotoxicity by inhibiting N-methyl-D-aspartate receptor-mediated calcium influx. Proc. Natl. Acad. Sci. USA 1998, 95, 2642-2647. [CrossRef] [PubMed]

54. Du, J.; Gray, N.A.; Falke, C.A.; Chen, W.; Yuan, P.; Szabo, S.T.; Einat, H.; Manji, H.K. Modulation of synaptic plasticity by antimanic agents: The role of AMPA glutamate receptor subunit 1 synaptic expression. J. Neurosci. 2004, 24, 6578-6589. [CrossRef] [PubMed]

55. Giusti, C.F.; Amorim, S.R.; Guerra, R.A.; Portes, E.S. Endocrine disturbances related to the use of lithium. Arq. Bras. Endocrinol. Metabol. 2012, 56, 153-158. [CrossRef] [PubMed]

56. Filippa, V.P.; Mohamed, F.H. Lithium Therapy Effects on the Reproductive System. In Psychiatry and Neuroscience Update; Springer: Cham, Switzerland, 2019; pp. 187-200.

57. Pfeifer, W.D.; Davis, L.; Van der Velde, C.D. Lithium accumulation in some endocrine tissues. Acta Biol. Med. Ger. 1976, 35, $1519-1523$ 